\section{AdDITIONS TO BLACK MILDEWS OF PAKHAL WildLifE SANCTUARY, Telangana, ANDHRA PRADESH, INDIA}

V.B. Hosagoudar ${ }^{1}$, Md. Khaja Moinuddin ${ }^{2}$, G. Bagyanarayana ${ }^{3}$ \& A. Sabeena ${ }^{4}$

1,4 Jawaharlal Nehru Tropical Botanic Garden \& Research Institute, Palode, Thiruvananthapuram, Kerala 695562, India

${ }^{1}$ Present address: Killa, Bilagi, Bagalkot District, Karnataka 587116, India

2,3 Department of Botany, Osmania University, Hyderabad, Andhra Pradesh 500007 India

${ }^{1}$ vbhosagoudar@rediffmail.com (corresponding author), ${ }^{2}$ khaja.moin83@gmail. com, ${ }^{3}$ gbagyan@gmail.com, ${ }^{4}$ asabeenarasheed@gmail.com

Andhra Pradesh is the fourth largest state in India by area with dense forests of $44,229 \mathrm{~km}^{2}$ and with $397 \mathrm{~km}^{2}$ of mangrove forests. The Srisailam Hill ranges are located in the middle of the state and the Tirumala-Tirupati hills are located in the south $\left(17^{0} 57^{\prime} \mathrm{N} \& 79^{\circ} 59^{\prime} \mathrm{E}\right)$. This state represents 5,400 flowering plants and the important forests are protected in four national parks and 22 wildlife sanctuaries. However, such an interesting state with the maximum area of Eastern Ghats is least explored for microfungi excepting the sporadic works on mycorrhizal fungi, rusts, powdery mildews and hyphomycetes. Hence, we have taken an interest in the systematic study of black mildews in the Pakhal Wildlife Sanctuary, around Pakhal Lake (Pakhal Kothaguda Forest Range in Warangal District and the present work is part of it.)

\section{Asterina woodfordiae}

V.P. Sahni, Mycopath. Mycol. Appl. 23: 330, 1964; Hosagoudar, Mycosphere 2: 771, 2012.

Material examined: TBGT 6401, 19.x.2012, on leaves of Woodfordia fruticosa (L.) Kurz (Lythraceae), Kamaram forest, Pakhal Kothaguda Forest Range, Warangal, coll. Md. Khaja Moinuddin.

This species is known from Jabalpur (Madhya Pradesh), Ratnagiri (Maharashtra), and is reported here for the first time from Andhra Pradesh.

\section{Asterina combreti}

Syd. \& P. Syd., Engl. Bot. Jahrb. 45: 264, 1910; Hosag., Mycosphere 2: 659, 2012.

Material examined: TBGT 6402, 19.x.2012, on leaves of Getonia floribunda Roxb. [Calycopteris floribunda (Roxb.) Lam. ex Poir.] (Combretaceae), Kamaram forest, Pakhal Kothaguda Forest Range, Warangal, coll. Md. Khaja Moinuddin.

This fungus is common throughout the southern Western Ghats and is reported here for the first time from Andhra Pradesh.

\section{Schiffnerula cryptolepidis}

(M.S. Patil \& Thite) S. Hughes, Pleomorphy in some hyphopodiate fungi, p. 133, 1987; Hosag., Plant pathology and quarantine 1: 177, 2011.

Material examined: TBGT 6403, 19.x.2012, on leaves of Cryptolepis dubia (Burm.f.) M.R. Almeida [Cryptolepis buchananii Roem. \& Schult.] (Apocynaceae), Kamaram forest, Pakhal Kothaguda Forest Range, Warangal, Eastern Ghats, coll. Md. Khaja Moinuddin.

This species was known from the Western Ghats region of Maharashtra and is reported here for the first time from Andhra Pradesh.

DOI: http://dx.doi.org/10.11609/JoTT.03565.4901-3

Editor: B. Shivaraju, Bengaluru, India.

Date of publication: 26 October 2013 (online \& print)

Manuscript details: Ms \# 03565 | Received 25 March 2013 | Final received 02 September 2013 | Finally accepted 29 September 2013

Citation: Hosagoudar, V.B., M.K. Moinuddin, G. Bagyanarayana \& A. Sabeena (2013). Additions to black mildews of Pakhal Wildlife Sanctuary, Telangana, Andhra Pradesh, India. Journal of Threatened Taxa 5(14): 4901-4903; http://dx.doi.org/10.11609/JoTT.03565.4901-3

Copyright: @ Hosagoudar et al. 2013. Creative Commons Attribution 3.0 Unported License. JoTT allows unrestricted use of this article in any medium, reproduction and distribution by providing adequate credit to the authors and the source of publication.

Funding: UGC RFMS scholarship.

Competing Interest: Authors declare no competing interests.

Acknowledgements: The authors express their thanks to Dr. P.G. Latha, Director, JNTBGRI, Palode for the facilities and to Prof. V.S. Raju for the valuable suggestions. Md. Khaja Moinuddin is grateful to the Osmania University authorities for the award of a UGC RFMS scholarship. 


\section{Prillieuxina ixorigena}

Hosag. \& Chandrapr., Indian J. Sci. Technol. 2: 18, 2009; Hosagoudar, Mycosphere 2: 787, 2012.

Material examined: TBGT 6404, 19.x.2012, on leaves of Ixora pavetta Andr. [Ixora arborea Roxb. ex Sm.; Ixora decipiens DC.; Ixora parviflora Vahl; Ixora parviflora var. zeylanica Hook.f.] (Rubiaceae), Kamaram forest, Pakhal Kothaguda range, Warangal, Eastern Ghats, coll. Md. Khaja Moinuddin.

This species is known from Kerala and is reported here for the first time from Andhra Pradesh.

\section{Sarcinella chloroxyli sp. nov.}

Hosag., Moinud., Bagyan. \& A. Sabeena

(Image 1, Fig. 1; MycoBank \# 805910)

Colonies epiphyllous, thin to subdense, up to $2 \mathrm{~mm}$ in diameter, confluent. Hyphae flexuous to crooked, branching irregular at acute to wide angles, loosely reticulate, cells $15-27 \times 2-5 \mu \mathrm{m}$. Appressoria alternate to unilateral, ovate, globose, mammiform, broad based, entire, 5-10x5-10 $\mu \mathrm{m}$; conidiophores micronematous, mononematous, 1-2 septate, $7-10 \times 2-10 \mu \mathrm{m}$; conidiogenous cells terminal, monoblastic, cylindrical; conidia blastic, terminal, solitary, sarciniform, 2-5 celled, constricted at the septa, brown to charcoal black, 20-25x25-27 $\mu \mathrm{m}$, wall smooth.

Material examined: TBGT 6406, 19.x.2012, on leaves of Chloroxylon swietenia DC. (Flindersiaceae), Kamaram forest, Pakhal Kothaguda Forest Range, Warangal, Eastern Ghats, coll. Md. Khaja Moinuddin.

This is the first report of a schiffnerulaceous fungus on the members of the family Flindersiaceae (Hosagoudar 2003, 2011).

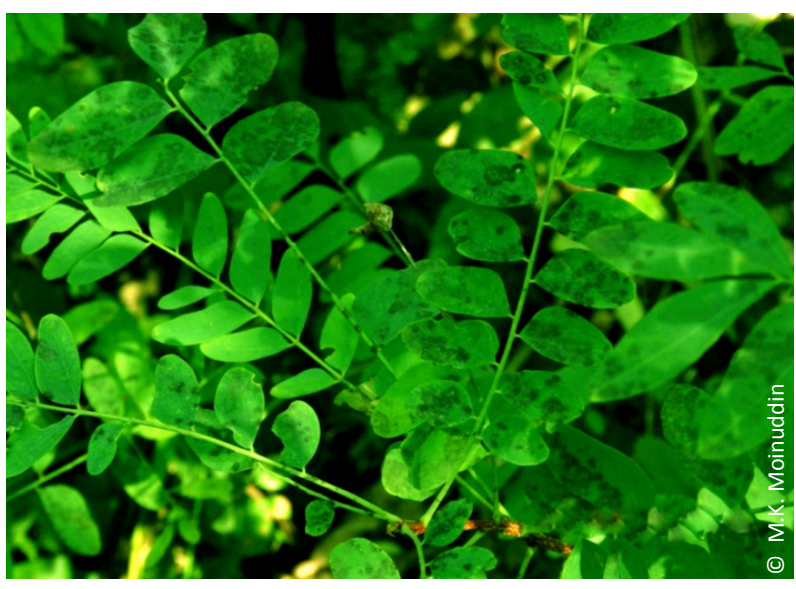

Image 1. Sarcinella chloroxyli sp. nov. symptoms produced on leaves of Chloroxylon swietenia

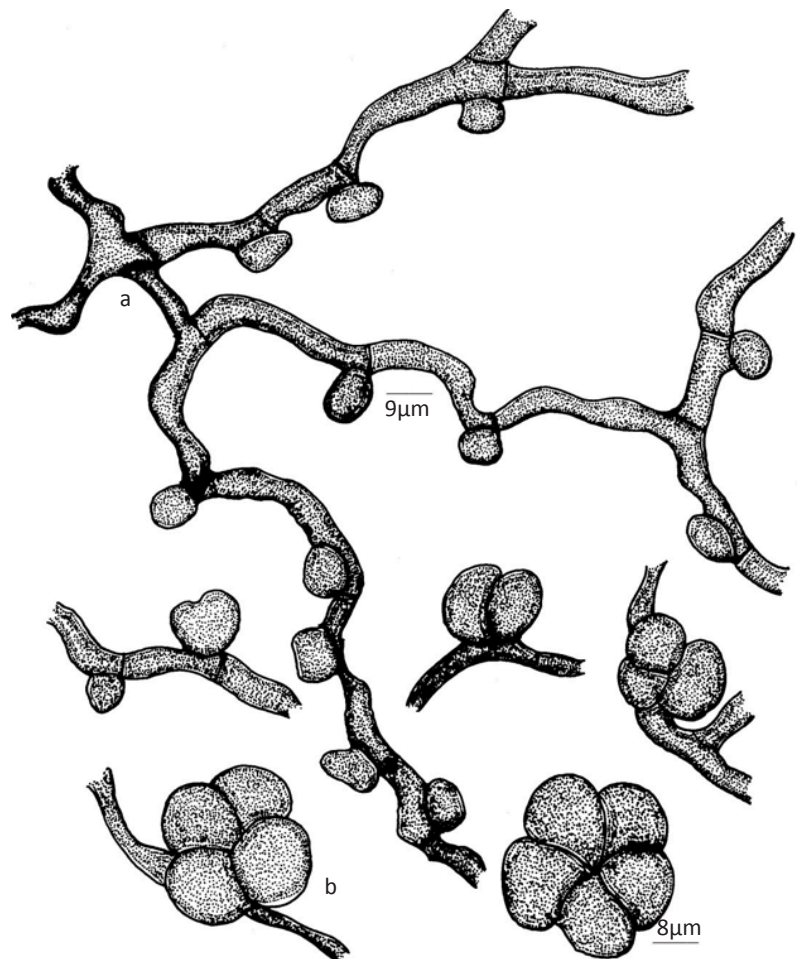

Figure 1. Sarcinella chloroxyli sp. nov. a - Appressoriate mycelium; b - Conidia

\section{Sarcinella gymnosporiae}

Subhedar \& Rao ex Hosag., Zoos' Print J. 17: 837, 2002; Hosag., PI. Pathol. \& Quarantine 1: 152, 2011.

Material examined: TBGT 6407, 19.x.2012, on leaves of Maytenus emarginata (Ruiz \& Pav.) Loes. [Gymnosporia emarginata (Willd.) Thwaites] (Celastraceae), Kamaram forest, Pakhal Kothaguda Forest Range, Warangal, Eastern Ghats, Md. Khaja Moinuddin.

This fungus is known on this host genus from the Western Ghats region of Maharashtra and is reported here for the first time from the Eastern Ghats.

\section{Sarcinella strychni sp. nov.}

\section{Hosag., Moinud., Bagyan. \& A. Sabeena}

(Image 2, Fig. 2; MycoBank \# 805911)

Colonies hypophyllous, thin, up to $2 \mathrm{~mm}$ in diameter, confluent. Hyphae flexuous, branching irregular at acute to wide angles, loosely reticulate, cells $15-20 x$ 2-5 $\mu \mathrm{m}$. Appressoria alternate to unilateral, globose, broad based, entire, 5-7 x 5-8 $\mu \mathrm{m}$. Conidia of Questieriella straight to curved, pale brown, 3-septate, mostly scattered in the colonies, 30-37x7-10 $\mu \mathrm{m}$. Sarcinella conidiophores produced laterally from the hyphae, single, straight, mononematous, 1-2 septate, 7-20x2-5 $\mathrm{mm}$; conidiogenous cells terminal, 


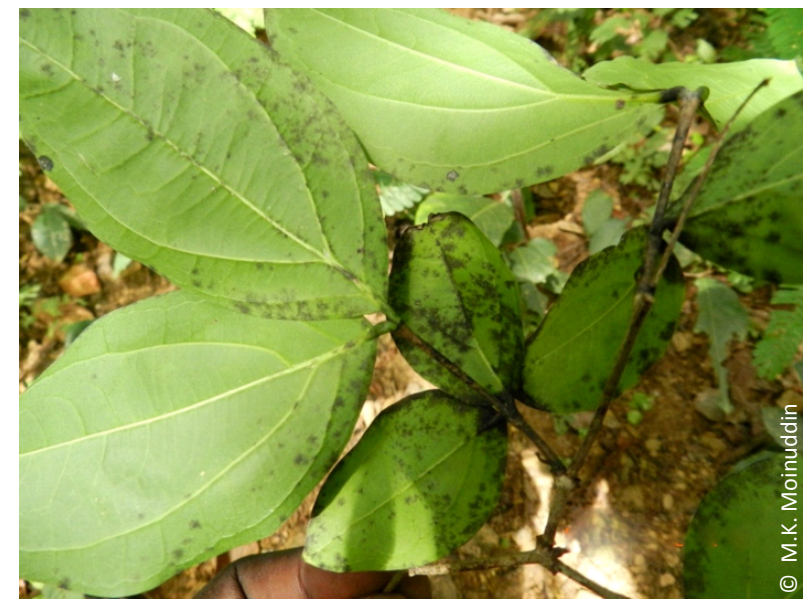

Image 2. Leaves of Strychnos potatorum infected with Sarcinella strychni sp. nov.

monoblastic, integrated, cylindrical. Sarcinella conidia blastic, terminal, solitary, ovate to globose, sarciniform, 2-6 celled, slightly constricted at the septa, brown to charcoal black, 20-30x17-27 $\mu \mathrm{m}$, wall smooth.

Material examined: TBGT 6405, 19.x.2012, on the leaves of Strychnos potatorum L.f. [Strychnos heterodoxa Gilg; Strychnos stuhlmannii Gilg] (Loganiaceae), Kamaram forest, Pakhal Kothaguda Forest Range, Warangal, Eastern Ghats, coll. Md. Khaja Moinuddin.

Questieriella strychni Hosag. is known on this host genus from Karnataka and Kerala states (Hosagoudar 2011) but the present collection differs from it in possessing both Questieriella and Sarcinella states. Hence, it has been placed in a distinct species.

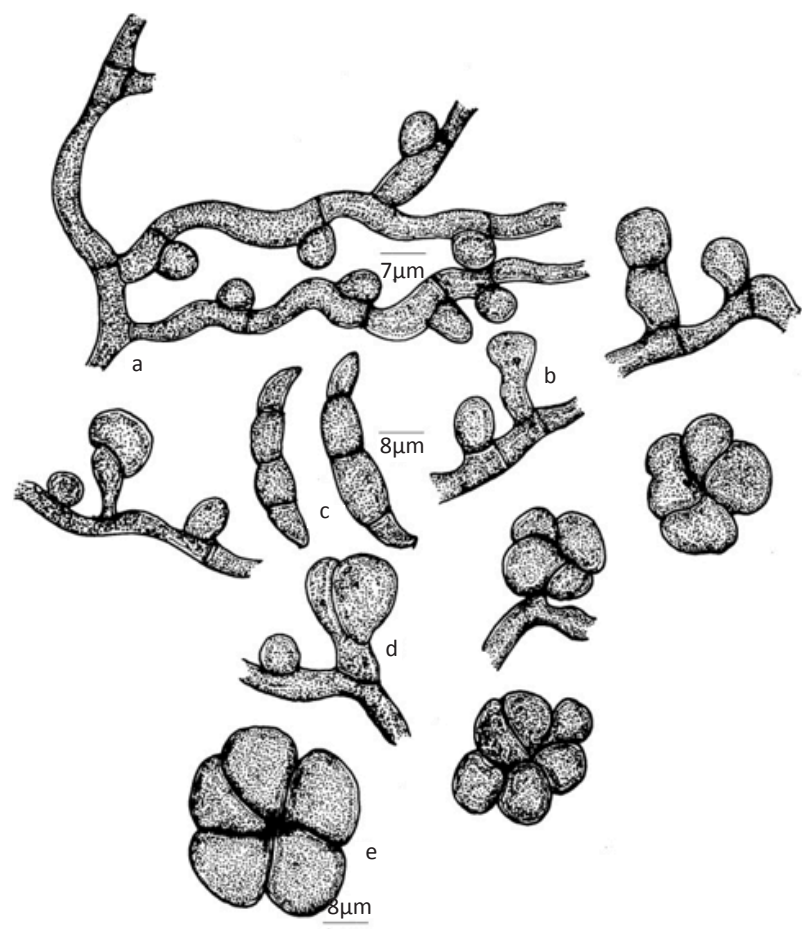

Figure 2. Sarcinella strychni sp. nov.

a - Appressoriate mycelium; b - Conidiophores of Questieriella;

c - Conidia of Questieriella; d - Conidiophores of Sarcinella; e - Conidia of Sarcinella

\section{REFERENCES}

Hosagoudar, V.B. (2003). The genus Schiffnerula and its synanamorphs. Zoos' Print Journal 18(4): 1071-1078; http://dx.doi.org/10.11609/ JoTT.ZPJ.18.4.1071-8

Hosagoudar, V.B. (2011). The genus Schiffnerula in India. Plant Pathology \& Quarantine 1(2): 131-204; http://dx.doi.org/10.5943/ $\mathrm{ppq} / 1 / 2 / 4$ 